\title{
RETHINKING RECOGNITION: THE CASE OF IRAQI KURDISTAN
}

\author{
Renad Mansour ${ }^{*}$
}

\begin{abstract}
The relationship of Iraqi Kurdistan to the Iraqi federal polity and the outside world challenges some of the standard assumptions in international law and international relations theory about statehood and de jure recognition. The Iraqi Kurdish model-building a de facto state first, and seeking international recognition later-provides an interesting counterpoint to the standard model and, for example, the Palestinian approach, which has focussed on international recognition before practical statecraft. The importance of international recognition in the current crisis involving the so-called Islamic State in Iraq and Syria, however, demonstrates that de jure recognition in the international community of states is still essential, and that 'sovereign' status likely remains the goal state desired by sub-national communities such as the Iraqi Kurds.
\end{abstract}

\section{Keywords}

Iraq, Federalism, Statehood, Sub-National Politics

As we approach the centenary of WWI, its legacies continue to impact world events. In the Middle East, post-war diplomatic efforts codified in the Sykes-Picot Agreement of 1916, Treaty of Sevres (1920) and Treaty of Lausanne (1923), carved out the borders of what would become the recognised states of today's Middle East (apart from Israel). These states were to be maintained by heavily centralised and militaristic governments. A recent wave of decentralisation has put these states and borders into question. The timeliest examples of this are Iraq and Syria. Both states were forcibly kept together by strong central governments in Baghdad and Damascus, despite a heterogeneous population housing a host of ethno-religious actors. The 2003 Iraq War and the 2011 Syrian Revolution fundamentally altered the almost 100-year old centralised structures in both states. In Iraq, the new buzzword became 'federalism', meaning decentralisation and the emergence of peripheral actors in their own right. The Kurds of northern Iraq are the most prominent case of de facto or empirical statehood to emerge from this period. In Syria, following 2011, several anti-regime actors have also emerged and gained attributes of traditional 'sovereignty', taking legitimacy away

\footnotetext{
Renad Mansour is a non-resident scholar at the Carnegie Middle East Center, a fellow at the Iraq Institute for Strategic Studies in Beirut, and a PhD Candidate at the University of Cambridge, where his research focuses on foreign policy and diplomacy.
}

Copyright $\odot$ the Author(s).

This work is licensed under a Creative Commons Attribution-NonCommercial-NoDerivs 3.0 License. 
from the regime of Bashar al-Assad. These actors include the so-called Islamic State (IS, or al-dawlat al-Islamiyya), the Kurds of Syria, the Al-Qaeda affiliate Jabhat al-Nusra, among several other opposition movements. IS, specifically, has declared itself as a new state extending across, and thus eliminating, the border between eastern Syria and western Iraq.

The current debates over the 'breakup' of Middle Eastern states are not only misguided but divert attention from the actual, more complex, reality: whilst the Great War's legacy of the nation-state in the Middle East lives on, it is no longer the be all and end all of sovereignty in Iraq, Syria or Lebanon. Since 1991, Kurdish Peshmerga have controlled the Kurdistan Regional Government (KRG)'s three provinces in northern Iraq, free from any interference from the central government. From roughly the same time, Hezbollah has enjoyed quasi-sovereignty over a large part of southern Lebanon, again free from any serious interference from the central government. Along with Syria after 2011, these three states have endured the proliferation of what might be called 'para-statal actors', all making claims of legitimacy in their use of violence against the monopoly that is regarded in the Weberian tradition as constitutive of statehood itself. ${ }^{1}$

This does not necessarily require the breakup of these states, but rather the realignment of power within each state. Contrary to much of the commentary in both international relations and international law, ${ }^{2}$ which still uses the concept of the 'state' as the ultimate tool for analysis, the argument put forward here is that de jure recognition is not the ultimate criterion of either legitimacy or effective 'sovereignty' in the region. Decentralisation in Iraq and Syria has facilitated a plethora of sub-states that effectively compete with established states for legitimacy and, in so doing, take sovereignty away from their central governments. In international diplomacy-the crucible in which internationally-recognised, de jure statehood is forged-this is explicitly linked to the question of 'who to talk to'. Understanding what is happening in the region, let alone forecasting what comes next, must rest on an understanding of the actors that legitimately claim to represent people and territory. The power to legitimise or de-legitimise representation has begun to erode, so that it is no longer solely the prerogative of central governments, or even national peoples. Who has the right to legitimise or delegitimise involvement or indeed representation is deeply contested.

\footnotetext{
1 See: M Weber, The Vocation Lectures: 'Science as a vocation'; 'Politics as a Vocation' (tr R Livingstone, 2004) 33-4.

2 See generally H Lauterpacht, Recognition in International Law (reissue 2013; 1947).
} 
This note examines the case of the Kurds in Iraq as an illustration of the current crisis of statehood. A pragmatic Kurdish leadership has moved beyond the stringent $20^{\text {th }}$ century notions of statehood to make its project the most successful of the cases that redefine sovereignty along sub-statal lines in the region.

\section{State-building without a state}

Immediately following WWI, the Kurds were promised a national state by the Treaty of Sevres. This promise, however, was later revoked by the Treaty of Lausanne, which split the Kurds among four states: Turkey, Iraq, Syria, and Iran. For much of the $20^{\text {th }}$ century, separate nationalist movements agitated for autonomy, self-determination, and independence on each side of the newly drawn states.

During this time, the Kurds of Iraq were the victims of various Arab nationalist regimes in Baghdad. This ultimately led to genocide in the 1980s. Out of tragedy came promise, however, as the UN, sponsored initially by the US, France, and UK, decided to establish a protectorate and no-fly zone in the Kurdish areas of Iraq following 1991. For the next decade, the KRG developed as a government separate from Baghdad. In effect, the international community had taken sovereignty away from Saddam Hussein's central government and established a de facto state in the country's north.

This placed the Kurds in a dilemma in 2003, when a US-led coalition toppled Saddam's regime: to continue on their path of independence and disassociation with Iraq, or to 're-marry' and become an autonomous province within a federal Iraq. The former was complicated due to three constraints. Geopolitically, all prospective neighbours and international supporters objected to an independent Kurdish state formed out of Iraqi territory. Economically, the Kurdistan Region was a landlocked territory in a hostile neighbourhood without the capacity to export its resources, particularly oil, or to sustain itself. Territorially, prior to independence, negotiations with Baghdad were necessary over the Kirkuk and Mosul territories, areas required for both economic and nationalist reasons. Against this backdrop, the Kurdish leadership decided in favour of the second option, to remarry Iraq, and became champions for a democratic and federal Iraq. The issue of independence became a bargaining tool, but in reality Erbil had a stake in the post-conflict governance in Iraq.

Since 2003, rather than pushing for formal de jure recognition, other than at a 
rhetorical level, Erbil has pursued a non-statist approach. To put it paradoxically, becoming a de jure state has not necessarily been part of the state-building process. This approach has focused on gaining empirical statehood before any serious motion for official recognition. This runs contrary to the 'Palestinian model', which emphasises official recognition as a necessary condition for state-building, despite complications with being granted that recognition. The KRG elite strategically decided to not antagonise larger players by declaring independence. Unlike their Palestinian counterparts, the Iraqi Kurd movement had not used independence' to evoke anxieties. Rather, the movement has sought autonomy within a democratic and federal Iraq. In fact, the Kurds were champions of federalism leading up to the 2003 regime change in Baghdad. The leadership has not taken the numerous opportunities presented, following the weakening of Baghdad, to break away from Iraq. Rather, it has demonstrated awareness of nationalism's limitations in addressing self-sustainability and the neighbourhood's opposition to independence. Moreover, it has also demonstrated tact in not evoking regional fears of pan-Kurdish nationalism.

\section{Drafting the Iraqi Constitution with Kurdish ink}

Empirical or de facto statehood is defined by the Montevideo Convention on the Rights and Duties of States 1933, which stipulates that a state must have (1) a permanent population, (2) a defined territory, (3) a government, and (4) the capacity to enter into relations with other states. ${ }^{3}$ The Kurdish leadership used the post-2003 constitution-making process as the key to their state-building project through attempting to establish the conditions stipulated by the Montevideo Convention. Iraq's supreme law, for the first time, recognised the distinct nation of the Kurds, and mandated Kurdish as one of two official languages, along with Arabic. If independence was not yet possible, then the new Iraq, as defined by the new constitution, would give the Kurds a de facto state. The constitution, therefore, was the top priority. The leadership astutely chose to invite international negotiation experts from North America and Europe to advance their position. Throughout the entire process, independence was used as a bargaining chip, or trump card, if demands were not met. The resulting Iraqi Constitution of 2005 met every Kurdish demand, and resulted in the

3 Convention on the Rights and Duties of States (Montevideo Convention), 26 December 1933, 165 LNTS 19, Art 1. 
KRG satisfying each condition in the Montevideo Convention. First, to ensure sovereignty over territory, Article 121 was significant:

First: the regional powers shall have the right to exercise executive, legislative, and judicial powers in accordance with this Constitution, except for those authorities stipulated in the exclusive authorities of the federal government. Second: In case of a contradiction between regional and national legislation in respect to a matter outside the exclusive authorities of the federal government, the regional power shall have the right to amend the application of the national legislation within that region. Third: Regions and governorates shall be allocated an equitable share of the national revenues sufficient to discharge their responsibilities and duties, but having regard to their resources, needs, and the percentage of their population. Fourth: Offices for the regions and governorates shall be established in embassies and diplomatic missions, in order to follow cultural, social, and developmental affairs. Fifth: The regional government shall be responsible for all the administrative requirements of the region, particularly the establishment and organization of the internal security forces for the region such as police, security forces, and guards of the region. ${ }^{4}$

Iraqi Kurdistan is the only part of the country legally considered to be a 'region' as defined by the Constitution. Article 121, in short, empowered the KRG to exercise several of the incidents of sovereignty over its territory. These included the power to maintain its own national guard rather than invite the Iraqi Security Force back in the Kurdistan Region.

To tackle the territorial impediment to independence, the Kurdish leadership lobbied for Article 140, which decrees the right to a referendum over the status of the oil city of Kirkuk, among other 'disputed territories' following a process of 'de-Arabisation' and resettling displaced Kurds in the territories. In other words, once the Arabs were removed, and the Kurds were brought back, Kirkuk would participate in a referendum and choose whether to join the KRG or to remain under the jurisdiction of Baghdad. To minimise the potential influence of Baghdad, and to address the fear of re-centralisation in the future, the KRG

\footnotetext{
${ }^{4}$ Iraqi Cabinet, 'Destour jumhuriyya al-Iraq', <http://www.cabinet.iq/PageViewer.aspx?id=2> [accessed 23 September 2014]. Constitution of the Republic of Iraq, Art 121, <http://www.iraqinationality.gov.iq/attach/iraqi_constitution.pdf> [accessed 10 December 2014].
} 
leadership also agitated for Article 121, which granted the power of regional law to 'amend the application of the national legislation within that region' in case of contradiction in matters outside the exclusive authority of the central government. ${ }^{5}$

The final move was to ensure that the Kurdish bloc had veto power over constitutional amendments at the time. Article 142(4), which in essence ruled that any amendments to the articles of the Constitution would be rejected if two-thirds of the population in three or more governorates voted against the amendment provided the KRG, made up of three governorates, with this veto power over the set of proposed amendments. ${ }^{6}$ Article 126(4), moreover, ensured that 'articles of the Constitution may not be amended if such amendment takes away from the powers of the regions that are not within the exclusive power of the federal authorities.?

The point of 'exclusive powers' is noteworthy. Article 110 sets out several competencies reserved for only the central government in Baghdad. The first exclusive power concerns foreign policy and diplomacy. Any offices for the regions abroad, according to Article 121(4), have to be part of the federal embassies in foreign capitals. Although it is an exclusive power, the KRG independently practices foreign affairs and diplomacy. Moreover, KRG now has de facto embassies, which are not within the Iraqi embassies but in separate buildings free from Iraqi interference and are concerned with explicitly political affairs. This exemplifies the KRG leadership's ability to work outside the confines of the Constitution, without repercussions from a weak central government.

Since 2003, legally or extra-legally, the KRG has sought to meet the Montevideo criteria and achieve empirical statehood. It has defined its permanent population as Kurdistani, rather than Kurdish, in order to include other ethnicities, such as Chaldeans, Assyrians, Yazidis, Turkmen, and Shabaks, living in Iraqi Kurdistan. The territory is indeed defined, thus far as the three provinces of Erbil, Duhok, adn Sulaimania - although it is expected to expand in wake of the ISIL crisis in Kirkuk and other 'contested' territories. It has established a government, the KRG, which is operating increasingly separate from Baghdad. Finally, Erbil

5 Ibid.

6 The analytical concept of 'veto players' is well recognised in political science and international relations, but less appreciated among lawyers. The concept is put to work with great effect in reference to the Parliament Acts in Iain McLean's chapter titled 'A Fresh Start: Veto Players, Win Sets, and Constitutional Moments' in I McLean, What's Wrong With the British Constitution? (2010) 29.

7 Constitution of the Republic of Iraq (above n 4), Art 126(4). 
has demonstrated the capacity to enter into foreign relations with other states, through a robust foreign policy, that will be explained in the following section. The leadership has set Iraqi Kurdistan on a state-building trajectory to continue moving toward and solidifying its satisfaction of the Montevideo criteria.

\section{Diplomacy as the lifeline}

If Erbil has already achieved empirical statehood, what is the useful function of independence? According to Scott Pegg, there are five core reasons why unrecognised movements seek recognition. First, without independence, an entity cannot turn to the UN for either verbal or material aid during a crisis. Second, the sub-state entity is unlikely to benefit from bilateral or multilateral treaties or alliances. Third, the international aid regime becomes quite limited. Fourth, the uncertain legal status works to deter investments and exports. Fifth, private firms will be reluctant to agitate the larger, central government of the host-state. ${ }^{8}$

Although the Constitution served to alleviate Erbil's anxieties at remaining part of Iraq, it was not enough to alleviate the Kurdish leadership's existential fears around being an unrecognised state. The document has proved to be more political than legal, and was hampered from the start by ineffective mechanisms for enforcement. Article 140, which called for a referendum in Kirkuk by December 2007, for example, has not been implemented to date. For the KRG, it became apparent that Baghdad would not necessarily abide by its own supreme law. Erbil did not trust the Iraqi central government to abide by the Constitution. It was perceived that more had to be done to ensure that Iraqi Kurdistan's statehood would continue unabated. ${ }^{9}$

The leadership turned to diplomacy as the avenue to bypass obstacles to independence in an environment of mistrust towards the central government and its equivocal respect for the constitution. Erbil had already mitigated the antagonism towards Kurdish independence by sticking to Iraq. Now, it searched for friends that could act as possible protectors. As the KRG's de facto Foreign Affairs Minister Falah Mustafa commented, 'you can't chose your neighbours, but you can chose your friends'. ${ }^{10}$ For the KRG leadership, choosing friends was the way to address its existential crisis. The outcome of its diplomatic efforts has

\footnotetext{
8 S Pegg, International Society and the De Facto State (1998) 50.

9 Interview with Fuad Hussein (Erbil, December 2013).

${ }^{10}$ Interview with Falah Mustafa (Cambridge, October 2013).
} 
now become evident: Islamic State in Iraq and the Levant (ISIL) did not attract Western intervention when it terrorised Syrians, nor when it invaded Fallujah in December 2013, nor even when it took over Mosul in June 2014. When it moved towards Erbil, the US mandated airstrikes overnight. ${ }^{11}$ The experience of Iraqi Kurdistan would seem to qualify some of Pegg's assertions. The following sections describe the process in which the KRG leadership can be seen to have used diplomacy to overcome Pegg's 'recognition problematic', ensuring that the international community has in fact addressed certain existential threats in Iraqi Kurdistan's favour despite its status as a sub-state entity.

\subsection{An unrecognised state cannot turn to the UN for verbal or material aid}

On the contrary, the UN saved Iraqi Kurdistan from an oppressive Saddam Hussein in 1991, after France, the UK, and the US established a safe haven (with material assistance) and condemned Saddam Hussein. The spillover from the Syrian civil war, beginning in 2011, put the Kurdistan Region on the humanitarian map. The KRG sought out the UN, which now works closely with Erbil. In fact, the Department of Foreign Relations (DFR) has allocated Dinar Zebari as the Head for International Organisations. His role, as he perceives it, is to maintain relations with non-government orgnanisations, including the UN. Since 2003, the UN presence has increased. There are some $400 \mathrm{UN}$ officials from $14 \mathrm{UN}$ agencies based in the region. ${ }^{12}$ In January 2014, moreover, the UN Secretary General flew to Erbil to meet with the senior leadership. Through the use of diplomacy, and the office of Zebari, the KRG has ensured that the UN is a strategic partner.

\subsection{An unrecognised state is unlikely to benefit from bilateral or multilateral treaties}

In November 2013, KRG PM Nechirvan Barzani and Turkish PM Recep Tayyip Erdogan signed a bilateral agreement concerning oil exports through pipelines, gas export, and export payment means. ${ }^{13}$ The process that led to this monumental

${ }^{11}$ H Cooper, M Landler \& A Rubin, 'Obama Allows Airstrikes against Iraq Rebels', NY Times, 8 August 2014, A1.

12 Interview with Dindar Zebari (Erbil, January 2013).

${ }^{13}$ W Khoudouri, 'Erbil-Ankara Oil Agreement Threatens Iraq's Unity', al-Monitor (online), 15 December 2013, <http://www.al-monitor.com/pulse/business/2013/12/oil-kurdistan-turkey- 
agreement is telling. Erbil's neighbours, particularly Turkey and Iran, historically feared Kurdish autonomy and political mobilisation due to the possible implications for their own Kurdish minorities. As a way of maintaining its de facto statehood and addressing the existential threat of non-recognition, the KRG leadership knew that building trust with Turkey was essential. This came in a strategy of non-antagonisms. The leadership made it clear that they did not seek to incite any unrest among the Turkish or Iranian Kurds. Politically, relations improved as trust increased, based primarily on economic and security interests; Erbil acting as a buffer from Iraq's constant instability and presenting itself as the 'Mosul wilayet', which was an Ottoman province that hosted a majority of the Kurds. The KRG leadership's idea was to play into Erdogan's neo-Ottomanist dreams.

For Erbil, diplomacy was trust-building. For Ankara and Erbil, then, the mutual interest was in stability. The Kurdish Region has proven both able to provide a stable environment for Turkish companies to expand in oil and gas and other sectors, and able to exert influence over potential hotspots with competing Kurdish parties that hold anti-Turkish views. For example, Syrian President Bashar al-Assad granted the Kurds in Syria autonomy in a move to destabilise Turkey for its meddling in the Syrian civil war. The leading Kurdish party, the Democratic Union Party (PYD), is closely linked with the PKK and this remains problematic for Turkey. Nonetheless, Ankara continues to work with Erbil in ensuring that the influence of the PYD does not grow or alter the regional equation. Here, again, the Kurdish Region is proving to be a strong Turkish partner. The overarching interest is in regional stability, rather than any threatening notion of pan-Kurdish nationalism. This stability, for both sides, is required for building mutual trust and to lead to much-needed economic development. ${ }^{14}$ Erbil proved to Turkey that it was committed to its newfound partnership and that it could work with Ankara in the region.

Whereas five years ago, Ankara-Erbil negotiations were always conducted vis-à-vis Baghdad or another state actor, as trust between the two developed, Ankara began engaging in direct talks with the KRG. Greater economic activity facilitated this rapprochement. The KRG has become Turkey's second largest trading partner and is on a trajectory to overtake Germany for that position. ${ }^{15}$

threat-baghdad.html\#> [accessed 23 September 2014].

${ }^{14}$ R Mansour, 'Iraqi Kurdistan and the Syrian-Kurd Pursuit of Autonomy' (Al-Jazeera Centre for Studies Report, 24 September 2012).

15 D Jones, 'Turkish Trade Ties with Iraqi Kurds Anger Baghdad', Voice of America (online), 20 December 2012, <http://www.voanews.com/content/turkey-trade-iraq-kurd/1569286.html> [accessed 23 September 2014]. 
The policy of trust-building and creating economic interdependencies, therefore, concluded with the signing of the bilateral treaty between the two. While Erdogan has not become the President of Turkey, his neo-Ottoman regional policies have questioned the assumption that unrecognised states cannot benefit from bilateral or multilateral treaties.

\subsection{An unrecognised state faces a limited international aid regime}

The presence of aid organisations, including UN agencies and USAID in the Kurdistan Region, after 1991 but more significantly after 2003, counteracts this assumption. ISIL had been terrorising large parts of Syria for several years. In December 2013, ISIL moved in and took over parts of Fallujah in Iraq. In June 2014, moreover, ISIL took over Mosul, Iraq's second largest city. During this process, the international aid regime was quite slow to provide support to both Iraq and Syria-two recognised states. It was only when ISIL decided to attack the Kurdish Peshmerga in Sinjar and other areas of northern Iraq that the international community, namely the US, decided to act swiftly.

How could a sub-state merit a response from the international community, where two states had previously been ignored? The answer to this is based on the KRG's diplomatic efforts in the past decade. To the US and the Western community, the leadership began positioning the KRG as 'the Other Iraq', a Western-friendly ally committed to the ideas of democracy and human rights. ${ }^{16}$ When the Obama administration was in negotiations to withdraw from Iraq in 2010, the Kurdish leadership made their anxieties well known, even offering the US permanent air bases in Kurdistan, as a token of their commitment. ${ }^{17}$ With the KRG a strategic ally for Washington, its existence as such became fundamental to US foreign policy in the region. The international aid community, therefore, acted to provide aid to the minorities in the Kurdistan Region, as well to fend ISIL away from the KRG's territories with airstrikes-which were not used to support either Iraq or Syria.

\footnotetext{
${ }^{16}$ Interview with Hemin Hawrami (Erbil, January 2014).

${ }^{17}$ M Rubin, 'Will America Leave Kurdistan?' American Enterprise Institute, 26 September 2011, <http://www.aei.org/article/foreign-and-defense-policy/regional/middle-east-andnorth-africa/will-america-leave-kurdistan/> [accessed 23 September 2014].
} 


\subsection{An unrecognised state's uncertain legal status deters investment and exports}

Erbil-Ankara relations are primarily based on economic considerations. Since being landlocked was a key impediment to independence for the KRG, diplomacy was again necessary for survival, especially for an economy dependent on the export of oil. The aforementioned trust-building between the KRG and Ankara was also based on mutual economic interests.

The leadership, therefore, fosters strong trade ties with Turkey and Iran, among others, to export its oil and establish interdependencies. The stability has attracted thousands of Turkish nationals, hundreds of Turkish companies, and several Turkish banks and schools to the Kurdish Region. With trade valued at nine billion dollars in 2013, some 30,000 Turks now live and work in Kurdistan. ${ }^{18}$

To further link Erbil and Ankara, a historic pipeline was completed in December 2013, connecting the Taq Taq oil fields in the Kurdistan Region to Fishkabur, Turkey. Most importantly, this pipeline does not go through Iraqi territory. Initial export level estimates include: $150,000 \mathrm{bpd}$ for the Taq Taq to Khurmala pipeline, 300,000 for the Khumala to Duhok pipeline, and 300,000 for the Duhok to Fishkabur (Turkey) pipeline. The expectation is for these levels to increase, and with such increases, the KRG elite hope to move away from economic dependence on Baghdad.

\subsection{An unrecognised state has difficulties attracting private firms, which fear agitating the central government}

Again, events on the ground in the Kurdistan Region question this assumption. Foreign investment has thrived in Erbil, making the region one of the fastest growing economically, even among states. To date, there is an estimated 46 billion US dollars worth of projects underway in the energy, construction, tourism, and basic infrastructure sectors.

Fearful of Kurdish economic independence, Baghdad is agitated by Erbil's move toward economic development, particularly in the oil and gas sector. To combat this, former Iraqi Oil Minister Shahrastani famously threatened to blacklist any company that deals with the KRG without Baghdad's approval. ${ }^{19}$

\footnotetext{
${ }^{18}$ S Kerr, 'Turkey: Economics and Energy Interests Ease Old Cross-Border Tensions', Financial Times, 9 December 2012.

${ }^{19} \mathrm{Al}$ Arabiya, 'Iraq Nullifies Kurdish Oil Contracts', al Arabiya, 24 November 2007, <http://www.alarabiya.net/articles/2007/11/24/42056.html> [accessed 04 December 2014].
} 
This deterrent did not last very long. Most famously, in 2011, Exxon Mobil, one of the largest oil and gas corporations, sacrificed its stake in Basra, southern Iraq, and moved to the KRG's jurisdiction, signing a Production Sharing Contract (PSC) with Erbil. ${ }^{20}$ Following this, several other private firms followed suit, including Total, Gazprom, and Chevron. ${ }^{21}$

Again, the above is the outcome of a concerted diplomatic effort to attract businesses into the Kurdistan Region. The KRG's Representative to the UK, a de facto Ambassador, Bayan Sami Abdul Rahman, claims that one of the top priorities of her representation is to present business opportunities to the UK. ${ }^{22}$ Declaring that 'Kurdistan [Iraq] is open for business,' the KRG passed an investment law in 2006 that offers foreign investors 100 percent ownership of their operations in Iraqi Kurdistan. The KRG actively seeks to invite trade delegations from Western capitals, and uses increased business ties and relations with influential world actors as another check against the existential threats associated with not being recognised and thus susceptible to being forgotten. Washington, in saving Erbil from ISIL, considered the great number of Americans working in the region, in oil and gas companies. This strategy seems to have put Erbil on the map.

\section{Conclusion: constantly negotiating}

Fakhri Karim, a senior Kurdish official, told the author that 'the Kurds have a state under the table. ${ }^{23}$ The KRG has its own armed force, the Peshmerga, which exercises effective control over its territory-even now against the onslaught of the ISIL. Iraq's security forces are prohibited from entering without Erbil's approval. The KRG administers its own foreign policy and sends its own separate representations abroad, independent from the Iraqi embassy in foreign capitals. The KRG also issues its own oil contracts and has recently built a pipeline and begun exporting its own oil, independent of Baghdad. These actions, which have traditionally been reserved for the state, pose the question: is official recognition necessary for autonomy, or has the KRG's leadership bypassed the 'territorial

\footnotetext{
${ }^{20}$ S Pfeifer, 'Big Oil: Exxon Move Shocks the Sector', Financial Times, 7 December 2014, <http://www.ft.com/cms/s/0/1a0e76ce-1a6d-11el-ae14-00144feabdc0.html\#axzz3EEnX5oSv> [accessed 24 September 2014].

${ }^{21}$ B Swint, 'Kurdistan's Oil Ambitions', Bloomberg Business Week, 14 November 2013, <http://www.businessweek.com/articles/2013-11-14/2014-outlook-kurdistans-oil-ambitions> [accessed 26 September 2014].

${ }^{22}$ Interview with Bayan Sami Abdul Rahman (London, April 2013).

${ }^{23}$ Interview with Fakhri Karim (Erbil, January 2014).
} 
trap' and achieved national self-determination without the need for a separate nation-state, at least as long as the likelihood of such an entity is doubtful?

The case of Iraqi Kurdistan shows those interested in transitional constitutionalism a successful instance of an alternative approach, one that places de facto state-building above de jure international recognition. Rather than moving for formal recognition as a state, the KRG's leadership has developed and worked with alternative, sub-national modes of sovereignty and governance. Although a strong sense of nationalism has motivated strong demand for independence by the Kurdish population, a pragmatically minded leadership has adroitly shifted away from the Palestinian 'recognition-before-state-building' model and toward a new model: state-building notwithstanding non-recognition. Erbil proactively ensured that the 2005 Iraqi Constitution was friendly to their decentralised ambitions. When it looked like the Constitution was not enough, the KRG used diplomacy to overcome the existential threats associated with lack of recognition. Whilst the KRG's leadership wants independence, it is aware of the structural realities of its environment, and plays within the bounds, pushing the envelope at times. Independence is used as a bargaining tool, and ultimately a veto play, to negotiate a list of demands that make the KRG a de facto independent entity. The case also demonstrates, however, that whatever route is taken, diplomacy and international recognition is ultimately still essential to survival in an international community populated by states; even a strong de facto state looks for international recognition for support in crises, and in some cases is able to obtain it. And it shows that full-fledged, de jure statehood will probably remain the end-goal in most cases. 